\title{
FOOD INDUSTRIES WASTE AS A VALUABLE SOURCE OF LIQUID ORGANIC FERTILIZER AND THEIR EFFECTS ON IMPROVING SALINE CALCAREOUS SOIL AND PLANTS Shreen Ahmed, S. ${ }^{*}$ and A. H. fahmy \\ * Soils, Water and Environment Research Institute, ARC, Giza, Egypt \\ ${ }^{* *}$ Agricultural Genetic Engineering Research Institute, Agricultural Research Center, Egypt
}

\begin{abstract}
The objective of this work is to assess the suitability of utilizing food industry wastes (molasses yeast and lemon waste) to produce natural liquid organic fertilizer and evaluation their effects on plants grown on saline calcareous soil. A preliminary experiment was conducted at the greenhouse of Agricultural Research Centre (ARC) at El-Giza Governorate, Egypt. This experiment was carried out to test the effect of molasses yeast or lemon waste extract on the growth of maize ( zea maize) during the summer season of 2011 followed with barley (Hordeum vulgare) during the winter season of 2011/2012. The field experiment was carried out to verifying the effect of molasses yeast or lemon waste extract on maize plants. The experiment was carried out at the experimental farm of Nubareia Research Station ARC. (El-Behira Governorate), Egypt. Grains of maize were sown in summer growing season of 2012. The obtained results showed that applying both molasses yeast or lemon waste extract to soil increases the amount of soil organic matter and decreases the ECe of the soil. Avery slightly differences were observed in $\mathrm{pH}$ and $\mathrm{CaCO}_{3} \%$ of soil. There is a positive effect of both molasses yeast or lemon waste on the growth of field crops. The application of molasses yeast and lemon extract significantly increased grain and straw yield as well as improved nutritional values of grain, i-e., total carbohydrates, crude protein, oil \%, total amino acids, organic acids, and hormones. The efficiencies of molasses yeast or lemon waste extract as a fertilizer or as amendments compared to control treatment are very different. There was excellent potential to obtain a natural fertilizer and amendment using molasses yeast. On the other hand, the best results of lemon waste extract were obtained as amendment only.

keywords: Industries wastes, plant extract, liquid organic fertilizer, soil amendment.

Calcareous soil
\end{abstract}

\section{INTRODUCTION}

The disposal of large volumes of waste materials can be an expensive and environmentally threatening operation. However, if alternative uses can be found, disposal costs can be avoided and added economic value can be obtained from the usage of waste materials (Inckel et al., 1996 and Sim and $\mathrm{Wu}, 2010)$. Heightened environmental awareness has led to an organic revolution, with scientists turning to organic materials in search of a comprehensive strategy to save soils from further degradation and utilize organic wastes in an environmentally safe manner. Liquid organic fertilizers can boost microbial activity in the soil while chemical fertilizers kill the active 
microorganisms (Kong et al., 2008). Organic compost fertilizer is a means to achieve fast results in a more natural and environmentally friendly way, as organic fertilizers can help to restore soil properties. The use of environmentally-friendly organic fertilizers is of special importance, because consumers are demanding higher quality and safer food and are highly interested in organic products (Ouda and Mahadeen 2008). Food industries waste is harmful, which seriously affected the urban environment and human health, but because of its rich in organic matter and fat content, therefore it has a greater utilization value, recover energy and produce the secondary product which is friendly to environment. Applied it to the cultivation of the plant can improve soil structure, increase soil fertility and promote crop growth. Not only reduce the burden of urban waste, but also promote the mass production of organic fertilizer, reducing fertilizer use, thereby reducing the pollution of soil and water by chemical fertilizer (Lan et al., 2012). Citrus fruits make up the largest sector of the world's fruit production, with more than 100 million tons produced each season. About $34 \%$ of citrus fruits are made into juices; therefore, large amounts of residues are formed every year (Li et al., 2006). The phytochemical analysis of the citrus peel extracts showed the presence of flavonoids, saponins, steroids, terpenoids, tannins and alkaloids (Ashok kumar et al., 2011). Guolin et al. (2012) mentioned that the lemon peels is in fact constituted by protein $3.16 \%$, fat $1.52 \%$, total carbohydrate $14.03 \%$, a crude fiber $9.50 \%$. Sugar industry wastes can be used as soil amendments to improve crop yield, soil physicochemical characteristics and provide a reasonable economic means to recycle these wastes in an environmentally friendly manner (Jamil and Qasim, 2008). The fermentative yeast Saccharomyces cerevisiae is largely used in ethanol production using such renewable biomass as sugar cane or sugar beet molasses as the main carbon source (Echegaray et al., 2000, Sanchez and Cardona, 2008). This molasses yeast is $100 \%$ pure Saccharomyces Cerevisiae yeast cultured on sugar cane molasses under carefully controlled conditions. After fermentation, the yeast is collected and dried using special spray dryers which preserve the protein digestibility of the yeast (Nofemele et al. 2012). The yeast is also used because of its high content of nutrients which are easily available and its high nutritional value. Calcareous soils exist in large areas particularly in semi-arid regions. In Egypt, most of the newly reclaimed soils are calcareous, the newly reclaimed land at Nubaria region reach about 900.000 feddan 290.000 feddan from them are calcareous (ElZaher et al., 2001). These soils are generally characterized by low fertility levels and easily ammonia volatilization due to their high content of calcium carbonate and alkaline $\mathrm{pH}$. In addition, the availability of most nutritional elements is considerably low especially phosphorus and micronutrients (Shata et a.,l 2007). The aim of the study is to assess the suitability of utilizing food industry wastes to produce liquid organic fertilizer, to decrease the use of chemical fertilizers and help in lowering the environmental hazards on a long-term basis. Evaluation the effects of liquid organic fertilizer on plants and soil are under study. 


\section{MATERIALS AND METHODS}

\section{Preparation of liquid organic fertilizer from food industries wastes}

Molasses yeast was obtained from sugar factory; El-hawamdia; Giza Governorate and lemon waste was obtained from Gohina factory; 6 October; Giza Governorate and then prepared as shown in Figure (1). These aqueous extracts were used as natural liquid organic fertilizers for maize and barley plants under saline calcareous soil. Greenhouse experiment was carried out at Giza, Agricultural Research Station, during summer season of 2011 followed by winter season 2011/2012, then field experiment during the winter season of 2012 at Nubareia Research Station, El-Behira Governorate. The final chemical analysis of molasses yeast and lemon waste extracts is shown in Table (1).

\begin{tabular}{|c|}
\hline Fig. 1b: Aqueous solution (P2) \\
$1 \mathrm{~kg}$ of lemon waste (peel, pulp, \& seeds) \\
$\downarrow$ \\
Cutting them into small pieces and were air-dried \\
prepared as a tea bag form \\
$\downarrow$ \\
The dried samples were ground properly using a mortar and pestle and \\
The bag soaked in 10 liter of hot tap water \\
$\downarrow$ \\
Soaked for $24 \mathrm{~h}$ at room temperature \\
$\downarrow$ \\
Chemical composition was determined \\
Cqueous extract transferred into sterile bottles and refrigerated until use \\
\end{tabular}

\begin{tabular}{|c|}
\hline Fig. 1a: Aqueous solution (P1) \\
Molasses yeast \\
$\downarrow$ \\
+ hot water $(1: 10 \mathrm{v} / \mathrm{v})$ \\
$\downarrow$ \\
Mixing well \\
$\downarrow$ \\
The solution stand for 4 hours under room temperature \\
$\downarrow$ \\
Finally the natural solution is kept in plastic bottle \\
$\downarrow$ \\
Determination of chemical composition
\end{tabular}

Figure1: Preparation of natural liquid organic fertilizer from food industry waste 


\section{Greenhouse experiment}

A preliminary experiment was conducted at the greenhouse of Agricultural Research Centre (ARC) at Giza Governorate, Egypt. This experiment was carried out to test the effect of molasses yeast or lemon waste extract on the growth of maize (zea maize) during the summer seasons of 2011 and followed by barley (Hordeum vulgare) during the winter seasons of 2011/2012, in the same pots after maize harvesting. Ten maize or twenty barley grain were planted in every pot $(20 \mathrm{~cm}$ diameter $)$ with three replicates, each pot contained $15 \mathrm{~kg}$ soil obtained from Nubareia Research Station (El-Behira Governorat). Experiment was designed in complete randomize design.

Table 1: Chemical composition of molasses yeast and lemon waste extract

\begin{tabular}{lcc}
\hline Chemical composition & $\begin{array}{c}\text { Molasses yeast } \\
\text { solution (P1) }\end{array}$ & $\begin{array}{c}\text { Lemon waste extract } \\
\text { (P2) }\end{array}$ \\
\hline Organic acids (\%) & 1.10 & 0.80 \\
\hline Gibrilic acid (mg/L) & 156.30 & 45.90 \\
\hline IAA (mg/L) & 203.70 & 138.60 \\
\hline Cytokinine (mg/L) & 11.80 & 2.10 \\
\hline Oil\% & 0.21 & 0.50 \\
\hline Crude protein\% & 3.75 & 1.30 \\
\hline Free amino acid \% & 2.60 & 0.60 \\
\hline Total soluble sugars\% & 15.50 & 10.70 \\
\hline pH(1:5) & 5.00 & 3.90 \\
\hline N\% & 0.60 & 0.20 \\
\hline K\% & 0.36 & 0.10 \\
\hline P\% & 0.03 & 0.02 \\
\hline
\end{tabular}

\section{Field experiment}

The field experiment was carried out to verifying the effect of molasses yeast ( $\mathrm{P} 1)$ or lemon waste extract (P2) on maize plants. Maize (zea maize) grains were planted in the experimental farm of Nubareia Research Station ARC, (El-Behira Governorate), Egypt. The experimental plot area was 10.5 $\mathrm{m}^{2}(3 \times 3.5 \mathrm{~m})$ with three replicates for each extract (P1 or P2) treatment and control treatment. Experiment was designed in a complete randomized block design. Grains of maize were sown in summer growing season of 2012. Some Physical and chemical characteristics of the studied soil before planting are presented in Table (2). The final plant sample was taken at the harvest. Collected samples were dried at $70{ }^{\circ} \mathrm{C}$ then kept for some analysis. It is worth mentioning, in both experiments, that P1 and P2 extract as natural fertilizers were added based on available $\mathrm{N}$ in each extract and requirements of $\mathrm{N}$ fertilizer for plant. While P1 or P2 extracts as a soil amendment were added at the rate of $2.5 \mathrm{~L} /$ plot from 1:10 extract (Sherif et al., 2012). The treatments of this experiment were: 
T1. Mineral fertilize (recommended dose)

T2. $\mathrm{P} 1$ or $\mathrm{P} 2$ as a fertilizer (recommended dose of $\mathrm{N}$-mineral fertilizer)

T3. P1 or P2 as amendment (2.5 L/polt) + Mineral fertilizer (recommended dose)

T4. P1 or P2 as amendment (2.5 L/polt) + Compost (recommended dose)

T5. P1 or P2 as a fertilizer (recommended dose of mineral $\mathrm{N}$-fertilizer) + some micronutrient ( $\mathrm{Fe}, \mathrm{Mn}, \mathrm{Zn}$ and $\mathrm{Cu})$

T6. P1 or P2 as amendment (2.5 L/polt) + Mineral fertilizer (recommended dose) + some micronutrient (Fe, $\mathrm{Mn}, \mathrm{Zn}$ and $\mathrm{Cu}$ )

T7. Compost as a recommended dose of mineral $\mathrm{N}$ - fertilizer

Table 2: Some physical and chemical properties of the tested soil under different experiments

\begin{tabular}{|c|c|}
\hline Physical properties & Value \\
\hline Sand\% & 8.00 \\
\hline Silt\% & 40.00 \\
\hline Clay\% & 52.00 \\
\hline Texture soil & Silty clay \\
\hline $\mathrm{CaCO}_{3} \%$ & 22.6 \\
\hline \multicolumn{2}{|l|}{ Chemical properties } \\
\hline $\mathrm{pH}(1: 2.5$, soil - water suspension) & 7.85 \\
\hline Organic matter (\%) & 0.7 \\
\hline ECe dS m${ }^{-1}$, soil paste extract & 8.18 \\
\hline \multicolumn{2}{|l|}{ Soluble cations $(\mathrm{me} / \mathrm{L})$} \\
\hline $\mathrm{Ca}^{++}$ & 27.38 \\
\hline $\mathrm{Mg}^{++}$ & 15.8 \\
\hline $\mathrm{Na}^{+}$ & 37.7 \\
\hline $\mathrm{K}^{+}$ & 0.93 \\
\hline \multicolumn{2}{|l|}{ Soluble anions (me/L) } \\
\hline $\mathrm{CO}^{=}=$ & \\
\hline $\mathrm{HCO}^{-}$ & 1.64 \\
\hline $\mathrm{Cl}^{-}$ & 43.5 \\
\hline $\mathrm{SO} 4=$ & 36.66 \\
\hline
\end{tabular}

\section{Analytical methods:}

Some Physical and chemical characteristics of the studied soil were determined according to Page et al., (1982). For digested plant sample and P1 or P2 extract; phosphorus content was determined by vanadomolybdate yellow method spectrophotometrically and $\mathrm{K}$ by a flame photometer (Jackson, 1973). Total nitrogen was determined by micro-Kjeldahl method according to AOAC. (1970). Crude protein was calculated by multiplying the values of total nitrogen with 6.25. Total free amino acids concentration was determined using ninhydrin reagent (Moore and Stein, 1954). Free proline was extracted and determined according to the method described by Bates et al., (1973). Indole-3-acetic acid was determined according to the method described by 
Mahadevan and Chandramohan (1966). Gibberellic acid was extracted and determined in plant tissue according to the method described by Cho, et al., (1979). Cytokinin was extracted and determined according to the methods of Unyayar et al., (1996). Crude oil was determined according AOAC. (1980).Total carbohydrate was extracted according to Smith, et al., (1964) and determined using a spectrophotometer according to Murphy (1958). All determinations were performed in triplicate and data represented on dry weight basis as mean values \pm standard deviations. At the end of season all plants were harvested and collected per plot and yield per feddan were then calculated. All data were statistically analyzed using Costat computer program according to procedures outlined by Snedecor and Cochran (1980).

\section{RESULTS AND DISCUSSION}

Effect of food industries waste extracts on organic matter, pH, calcium
carbonate and soil salinity
Applying aqueous solution, molasses yeast (P1) or lemon waste extract (P2) from food industries waste to soil increases the amount of soil organic matter in all treatments relative to mineral fertilizer and compost treatments (Fig. 2). A slightly differences were observed in soil $\mathrm{pH}$ and $\mathrm{CaCO}_{3}$ between most of treatments and mineral fertilizer or compost as shown in Fig. (3). Regarding the soil ECe, applying natural extracts (P1 or P2) from food industries waste led to decreases the ECe in all treatments relative to mineral fertilizer and compost treatments (Fig. 4). The lowest value of ECe was recorded in $\mathrm{P} 1$ with compost treatment; the decrease percentage reached $73 \%$ relative to mineral fertilizer as a control. Concerning the P2 extract, data show that, the lowest value was recorded at T2 treatment (P2 only); the decrease percentage reached $65 \%$ relative to mineral fertilizer as a control. Decreasing soil $\mathrm{pH}$ and soil salinity led to improving the availability of macro and micronutrients in the soil (Hetter, 1985) as well as yield productivity and its related characteristics (Kineber et al., 2004). 
J. Soil Sci. and Agric. Eng., Mansoura Univ., Vol. 5 (1), January, 2014
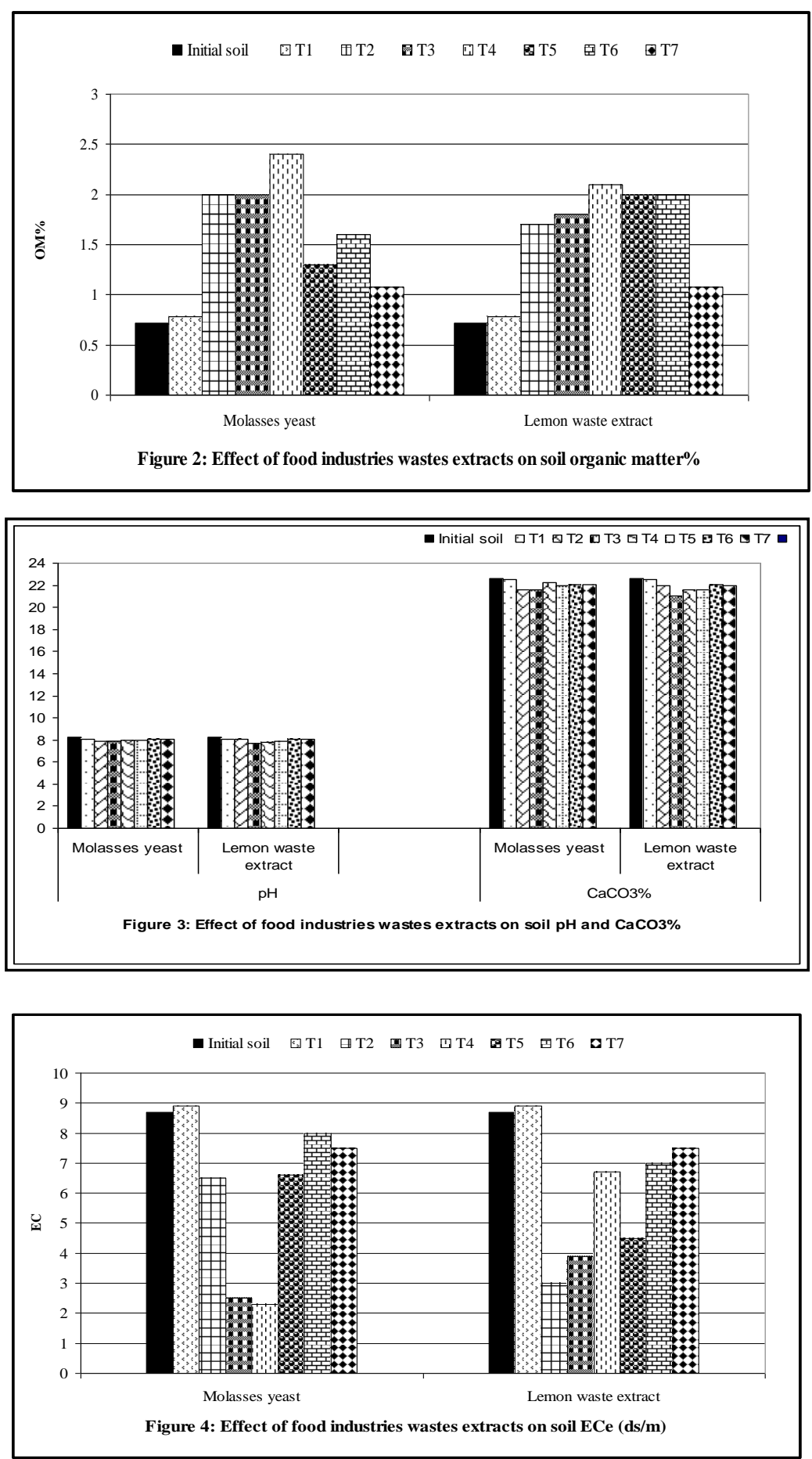


\section{Greenhouse experiment}

Grain and straw yield of maize plant:

Data of the effect of some food industry wastes solution on grain and straw yield of maize plant are presented in Table 3. Data reveal that addition of molasses yeast or lemon waste extract significantly increased grain and straw yield of maize relative to mineral fertilizer or compost treatments. The results show progressive increases in maize yield (grain or straw) as a result of addition molasses yeast (P1) compared with mineral fertilizer. Yield (grain or straw) reached 2.1 and 1.7-fold that of mineral fertilizer and compost, respectively. The grain or straw yield can be arranged in the following order: $T 3>T 6>T 7>T 5>T 4$. Regarding to the lemon waste extract (P2), the results showed progressive increases in maize yield (grain or straw) at T6 treatment. Grain and straw yield reached 1.9 and 1.6 -fold that of mineral fertilizer and compost treatments, respectively. The grain or straw yield can be arranged in the following order: $\mathrm{T} 6>\mathrm{T} 3>\mathrm{T} 4>\mathrm{T} 5>\mathrm{T} 2$. These results (increases in grain and straw yield) may be attributed to the presence of some growth regulator such as indole acetic acid, giberllic acid, organic acid, and amino acids in food industry wastes extracts (P1 or P2) as shown in table (1) and also to the combination effect of the extracts with mineral fertilizer and micronutrient.

Table (3): Effect of some food industry wastes extracts on grain and straw yield (g/pot) of maize plant under greenhouse experiment

\begin{tabular}{ccc}
\hline \multirow{2}{*}{ Treatment } & Grain yield & Straw yield \\
\cline { 2 - 3 } & \multicolumn{2}{c}{ Molasses yeast $(\mathrm{P} 1)$} \\
\hline T1 & $70.53^{\mathrm{g}}$ & $211.7^{\mathrm{f}}$ \\
T2 & $120.8^{\mathrm{c}}$ & $362.6^{\mathrm{c}}$ \\
T3 & $147.1^{\mathrm{a}}$ & $441.1^{\mathrm{a}}$ \\
T4 & $91.30^{\mathrm{e}}$ & $273.5^{\mathrm{d}}$ \\
T5 & $120.3^{\mathrm{d}}$ & $360.4^{\mathrm{c}}$ \\
T6 & $128.3^{\mathrm{b}}$ & $384.8^{\mathrm{b}}$ \\
T7 & $84.50^{\mathrm{f}}$ & $254.9^{\mathrm{e}}$ \\
LSD & 0.2923 & 2.643 \\
\hline & Lemon waste extract $(\mathrm{P} 2)^{\mathrm{g}}$ \\
\hline T1 & $70.53^{\mathrm{g}}$ & $211.7^{\mathrm{g}}$ \\
T2 & $92.47^{\mathrm{e}}$ & $277.5^{\mathrm{e}}$ \\
T3 & $128.0^{\mathrm{b}}$ & $383.6^{\mathrm{b}}$ \\
T4 & $118.1^{\mathrm{c}}$ & $354.1^{\mathrm{c}}$ \\
T5 & $99.17^{\mathrm{d}}$ & $297.7^{\mathrm{d}}$ \\
T6 & $136.3^{\mathrm{a}}$ & $408.7^{\mathrm{a}}$ \\
T7 & $84.50^{\mathrm{f}}$ & $254.9^{\mathrm{f}}$ \\
\hline LSD & $0.9711^{1}$ & 2.639 \\
\hline
\end{tabular}




\section{Grain and straw yield of barley plant:}

Data of the effect of some food industry wastes extracts on grain and straw yield of barley plant are presented in Table 4. Data show that addition of molasses yeast (P1) or lemon waste (P1) extract significantly increased grain and straw yield of barely relative to mineral fertilizer or compost treatments. The results show progressive increases in barley yield (grain or straw) at T3 treatment as a result of addition of $\mathrm{p} 1+$ mineral fertilizer. Regarding to the lemon waste extract (P2), the results show progressive increases in barley yield (grain or straw) at T6 treatment. Grain yield reached 1.4 and 1.3-fold that of mineral fertilizer and compost, respectively. Straw yield reached 1.2 and 1.2-fold that of mineral fertilizer and compost, respectively. It is worth to mention that, the minimum yield was found in P2 as fertilizer treatment (T2). These results (decreasing a grain and straw yield) may be due to the low concentration of nitrogen, phosphorous and potassium in P2 extract as shown in Table (1).

Table (4): Effect of some food industry wastes extracts on grain and straw yield $(\mathrm{g} / \mathrm{pot})$ of barley plant under greenhouse experiment

\begin{tabular}{|c|c|c|}
\hline \multirow{2}{*}{ Treatment } & Grain yield & Straw yield \\
\hline & \multicolumn{2}{|c|}{ Molasses yeast $(\mathrm{P} 1)$} \\
\hline $\mathrm{T} 1$ & $15.40^{g}$ & $74.03^{g}$ \\
\hline $\mathrm{T} 2$ & $23.47^{c}$ & $89.00^{b}$ \\
\hline T3 & $27.03^{a}$ & $112.0^{a}$ \\
\hline T4 & $18.30^{\mathrm{e}}$ & $77.67^{\mathrm{e}}$ \\
\hline T5 & $20.27^{d}$ & $80.20^{d}$ \\
\hline T6 & $25.30^{b}$ & $83.50^{c}$ \\
\hline \multirow[t]{2}{*}{ T7 } & $17.07^{f}$ & $75.80^{f}$ \\
\hline & 0.5396 & 0.9969 \\
\hline LSD & \multicolumn{2}{|c|}{ Lemon waste extract (P2) } \\
\hline T1 & $15.40^{d}$ & $74.03^{f}$ \\
\hline $\mathrm{T} 2$ & $12.63^{f}$ & $38.37^{\mathrm{g}}$ \\
\hline T3 & $19.33^{b}$ & $89.67^{b}$ \\
\hline T4 & $19.20^{b}$ & $80.27^{c}$ \\
\hline T5 & $14.40^{\mathrm{e}}$ & $78.40^{d}$ \\
\hline T6 & $22.20^{\mathrm{a}}$ & $94.23^{a}$ \\
\hline T7 & $17.07^{\mathrm{c}}$ & $75.80^{e}$ \\
\hline LSD & 0.3132 & 0.9985 \\
\hline
\end{tabular}




\section{Field experiment}

Grain and straw yield of maize plant:

The effect of some food industry wastes extracts on yield components of maize plant are shown in Table 5. Data explain that, addition of molasses extract (P1) significantly increased grain and straw yield of maize relative to mineral fertilizer or compost treatments as a control. The results show progressive increases in maize grain yield at treatments T2 and T3. The grain yield can be arranged in the following order: T2, T3>T6> T5>T4, T1. The biggest value of straw yield was observed at T3. Straw yield reached 2.5 and 2.1 -fold that of mineral fertilizer and compost, respectively. Regarding to the lemon waste extract (P2), the results show progressive increases in maize components yield at T6 treatment. Grain yield reached 2.0 and 1.9-fold that of mineral fertilizer and compost, respectively. The grain yield can be arranged in the following order: T6>T4>T3. No significant effect was found between the other treatments. The biggest value of straw yield was observed at T6 treatment. Straw yield reached 2.0 and 1.7-fold that of mineral fertilizer and compost, respectively. The straw yield can be arranged in the following order: $\mathrm{T} 6>\mathrm{T} 3, \mathrm{~T} 4>\mathrm{T} 5>\mathrm{T} 7>\mathrm{T} 1>\mathrm{T} 2$. It is worth to mention, that applying molasses yeast as amendment with compost (T4 treatment) was less affected on yield compared with applying molasses yeast as amendment with mineral fertilizer (T3 treatment), this result may be due to the interaction between microorganisms in soil. Lucia, et al., (2010) stated that the bacterial inhibition by yeasts is the most common interaction. While the opposite results (increasing in grain and straw yield) may be due to each extract comprise important sources of plant promoters such as sugars, lipids, carbohydrates, minerals such as N, P, K, inorganic compounds (Djilas et al., 2009). Generally, applying some liquid extracts of food waste industry as a fertilizer or amendment (fig.5 and 6) was more effective in stimulation of plant growth (fig.7 and 8). These results supported by Li et al., (2009). They stated that liquid natural fertilizer produced from waste was much cheaper compared to chemical fertilizer. Besides this advantage, liquid organic fertilizers from factory waste are easily available and have almost no adverse effect on the environment, while chemical fertilizers might cause nitrogen losses to groundwater streams and lakes causing pollution.

\section{Mineral Contents:}

The results of plant minerals content are summarized in Table (6). There was a difference in mineral content as a result of adding molasses yeast $(\mathrm{P} 1)$ or lemon extract $(\mathrm{P} 2)$ treatments and control. The highest values of nitrogen content were recorded in T3 treatment and T6 treatment. The biggest value of phosphorous content was recorded in T2 and T3 treatments. The highest value of potassium was recorded in T6 treatment. Regarding the lemon waste extract (P2), the highest values of nitrogen content were recorded in T4 and T6 treatments. The biggest value of phosphorus content was observed in T4 and T6 treatments. The highest value of potassium content was recorded in T6 treatment. Finally, from the previously obtained results, increase in minerals content in plants that treated with both extracts 
(P1 or P2) compared with mineral fertilizer or compost was observed. Generally, it could be concluded that the nutrient contents in maize grains were extending parallel close to the corresponding nutrients contents in both two extracts $\mathrm{P} 1$ and $\mathrm{P} 2$.

Table (5): Effect of some food industry wastes extracts on yield components (ton/fed.) of maize plant under field experiment

\begin{tabular}{cccc}
\hline Treatment & Grain & Straw & Biological \\
\cline { 2 - 4 } & \multicolumn{3}{c}{ molasses extract (P1) } \\
\hline T1 & $2.4^{\mathrm{d}}$ & $2.9^{\mathrm{d}}$ & $5.3^{\mathrm{e}}$ \\
T2 & $5.3^{\mathrm{a}}$ & $4.9^{\mathrm{b}}$ & $10.2^{\mathrm{b}}$ \\
T3 & $4.9^{\mathrm{a}}$ & $7.2^{\mathrm{a}}$ & $12.1^{\mathrm{a}}$ \\
T4 & $2.2^{\mathrm{d}}$ & $3.1^{\mathrm{cd}}$ & $5.3^{\mathrm{e}}$ \\
T5 & $2.8^{\mathrm{c}}$ & $3.3^{\mathrm{cd}}$ & $6.1^{\mathrm{d}}$ \\
T6 & $4.4^{\mathrm{b}}$ & $4.5^{\mathrm{b}}$ & $8.9^{\mathrm{c}}$ \\
T7 & $2.5^{\mathrm{cd}}$ & $3.5^{\mathrm{c}}$ & $6.0^{\mathrm{de}}$ \\
\hline LSD & 0.4394 & 0.4740 & 0.7548 \\
\hline \multicolumn{4}{c}{ Lemon waste extract (P2) } \\
\hline T1 & $2.4^{\mathrm{c}}$ & $2.9^{\mathrm{e}}$ & $5.3^{\mathrm{de}}$ \\
T2 & $2.3^{\mathrm{c}}$ & $2.3^{\mathrm{f}}$ & $4.6^{\mathrm{e}}$ \\
T3 & $3.7^{\mathrm{b}}$ & $4.8^{\mathrm{b}}$ & $8.5^{\mathrm{b}}$ \\
T4 & $4.0^{\mathrm{ab}}$ & $5.2^{\mathrm{b}}$ & $9.2^{\mathrm{b}}$ \\
T5 & $2.8^{\mathrm{c}}$ & $4.5^{\mathrm{c}}$ & $7.3^{\mathrm{c}}$ \\
T6 & $4.7^{\mathrm{a}}$ & $5.9^{\mathrm{a}}$ & $10.6^{\mathrm{a}}$ \\
T7 & $2.5^{\mathrm{c}}$ & $3.5^{\mathrm{d}}$ & $6.0^{\mathrm{d}}$ \\
\hline LSD & 0.7442 & 0.4358 & 1.063 \\
\hline
\end{tabular}

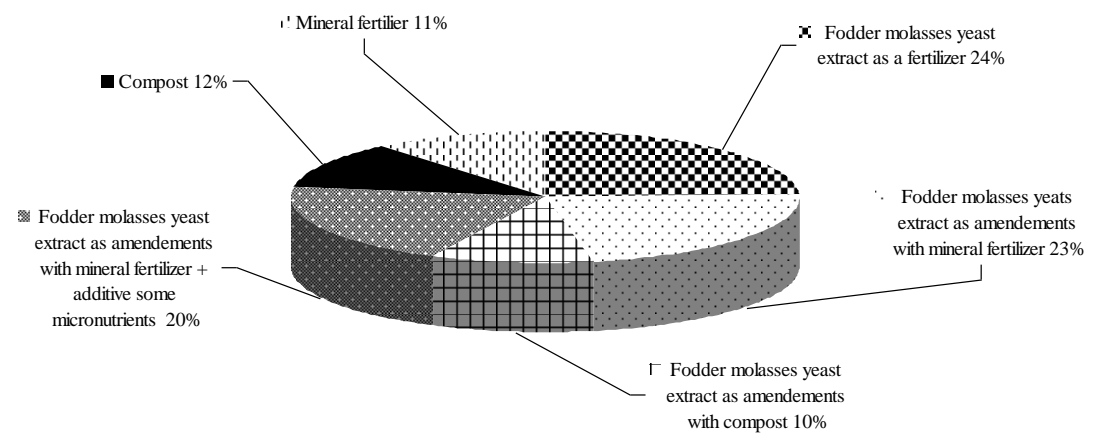

Figure 5 : The effect of molasses yeast as a fertilizer and amendements based on grain yield of maize plant under field experiment 


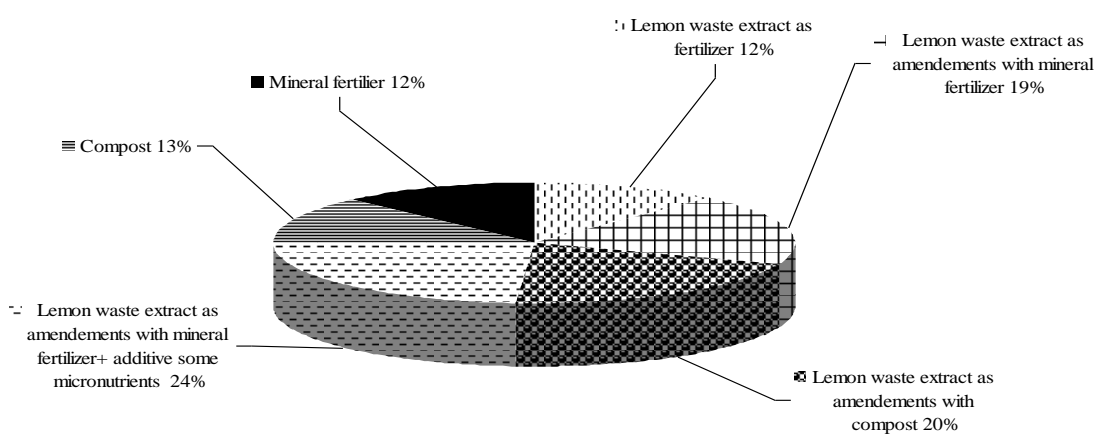

Figure 6 : The effect of lemone waste extracts as a fertilizer and amendements based on grain yield of maize plant under field experiment

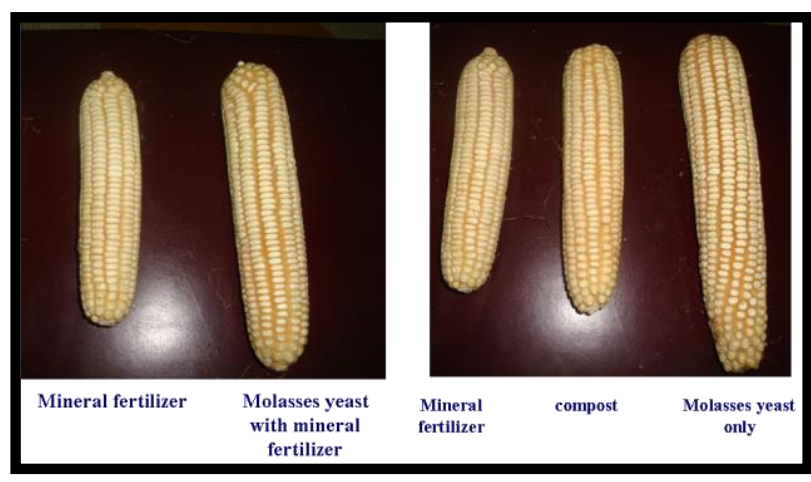

Figure 7: The effect of molasses yeast as a fertilizer and soil amendments of maize

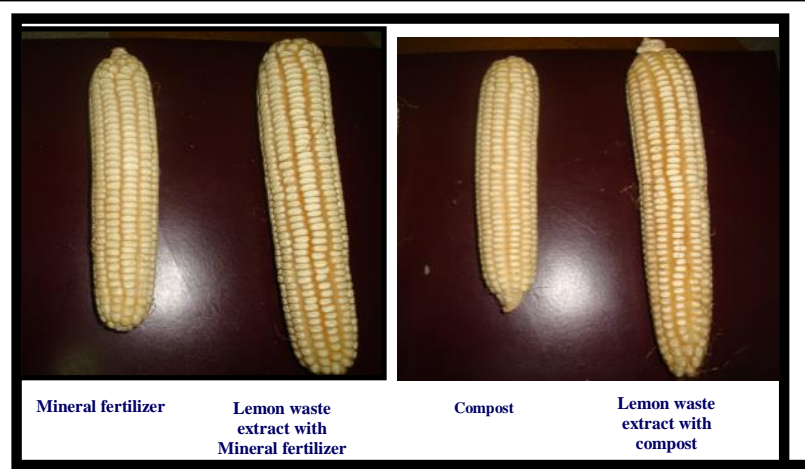

Figure 8: The effect of lemon waste extract as a soil amendment of maize 
Table (6): Effect of some food industry wastes extracts on mineral content $(\mathrm{g} / \mathrm{100 \textrm {g }}$ dry matter) of maize plant under field experiment

\begin{tabular}{|c|c|c|c|}
\hline \multirow[t]{2}{*}{ Treatment } & $\mathbf{N}$ & $\mathbf{P}$ & K \\
\hline & \multicolumn{3}{|c|}{ molasses yeast $(\mathrm{P} 1)$} \\
\hline T1 & $0.81^{d}$ & $0.12^{c}$ & $0.30^{b}$ \\
\hline T2 & $1.32^{b}$ & $0.29^{a}$ & $0.38^{\mathrm{ab}}$ \\
\hline T3 & $1.82^{\mathrm{a}}$ & $0.29^{a}$ & $0.30^{\mathrm{b}}$ \\
\hline T4 & $1.29^{b}$ & $0.23^{b}$ & $0.40^{\mathrm{ab}}$ \\
\hline T5 & $1.31^{\mathrm{b}}$ & $0.22^{b}$ & $0.41^{\mathrm{ab}}$ \\
\hline T6 & $1.75^{\mathrm{a}}$ & $0.20^{b}$ & $0.46^{\mathrm{a}}$ \\
\hline $\mathrm{T} 7$ & $1.04^{c}$ & $0.17^{\mathrm{bc}}$ & $0.38^{a b}$ \\
\hline \multirow[t]{2}{*}{ LSD } & 0.07956 & 0.05626 & 0.09744 \\
\hline & \multicolumn{3}{|c|}{ Lemon waste extract (P2) } \\
\hline T1 & $0.81^{c}$ & $0.12 \stackrel{d}{d}$ & $0.30^{b}$ \\
\hline T2 & $1.17^{\mathrm{ab}}$ & 0.24 bc & $0.38^{\mathrm{b}}$ \\
\hline T3 & $1.17^{a b}$ & $0.31^{a b}$ & $0.30^{\mathrm{b}}$ \\
\hline T4 & $1.23^{a}$ & $0.35^{a}$ & $0.38^{\mathrm{b}}$ \\
\hline T5 & $1.14^{\mathrm{ab}}$ & $0.29^{a b}$ & $0.40^{b}$ \\
\hline T6 & $1.29^{\mathrm{a}}$ & $0.37^{a}$ & $0.61^{a}$ \\
\hline T7 & $1.04^{b}$ & 0.17 cd & $0.38^{b}$ \\
\hline LSD & 0.1688 & 0.07956 & 0.09744 \\
\hline
\end{tabular}

\section{Chemical and biochemical parameters of plants:}

Total carbohydrates, crude protein and oil in maize grain

The responses of maize plant to different treatments were obvious from the variations among the total carbohydrates, protein and oil in maize grain (Table 7). For molasses yeast (P1) treatments, the highest value of total carbohydrate was observed in T2 and T3 treatments, which reached 1.2 and 1.1-fold that of mineral fertilizer or compost followed by T5 treatment which reached 1.2 and 1.1-fold that of mineral fertilizer or compost as a control, respectively. The lowest value was observed in treatment of mineral fertilizer. The highest value of crude protein was observed in T2 and T3 treatments compared to control. No significant effect was observed in T4, T5 and T6 treatments, while the lowest value was recoded in treatment of mineral fertilizer also. Concerning the oil content, the highest value was observed in treatments of T2, T3, T5 and T6. While, the values of oil contents were in the same values in the T1, T7and T4. Regarding the lemon waste extracts (P2) treatments. The highest value of total carbohydrate was observed in treatment of T5 treatment, which reached 1.2 and 1.1-fold that of mineral fertilizer or compost. On the other hand, the values of total carbohydrate contents were in the same behavior in the T2, T3 and T6 treatments. The values of crude protein were arranged in the following order: T4, T6 > T2, T3, and T5 treatment, while the lowest value was observed in treatment of mineral fertilizer only. The highest value of oil content was observed in T3, T4, and T6 followed T5 treatment compared to control. On the other hand, the lowest value of oil contents was observed in T1 and T7. These results 
may be attributed to that the $\mathrm{P} 1$ or $\mathrm{P} 2$ extract contains organic materials, and minerals such as N, P, K, as shown in table (1). Carbohydrates and other components that found in extracts can mobilization and translocation very easily from soil to plants. Fathy et al. (2009) found that increasing $\mathrm{N}$ and $\mathrm{K}$ rates significantly increased roots and sugar yield in sandy calcareous soil. Nelson (1978) found that potassium has a positive effect in plant growth under saline conditions, because it plays an essential role in stomata movement, photosynthesis and regulation of osmotic pressure for plant.

Table (7): Effect of some food industry wastes extracts on chemical components of maize plant under field experiment

\begin{tabular}{cccc}
\hline Treatment & Total carbohydrate\% & Protein\% & Oil \% \\
\cline { 2 - 4 } & \multicolumn{3}{c}{ Molasses yeast (P1) } \\
\hline T1 & $61.43^{\mathrm{e}}$ & $5.06^{\mathrm{a}}$ & $3.80^{\mathrm{D}}$ \\
T2 & $75.53^{\mathrm{a}}$ & $11.23^{\mathrm{a}}$ & $5.20^{\mathrm{a}}$ \\
T3 & $75.33^{\mathrm{a}}$ & $11.40^{\mathrm{a}}$ & $5.50^{\mathrm{a}}$ \\
T4 & $68.50^{\mathrm{c}}$ & $8.06^{\mathrm{b}}$ & $3.80^{\mathrm{D}}$ \\
T5 & $72.10^{\mathrm{D}}$ & $8.17^{\mathrm{D}}$ & $5.57^{\mathrm{a}}$ \\
T6 & $69.23^{\mathrm{c}}$ & $8.28^{\mathrm{D}}$ & $5.13^{\mathrm{a}}$ \\
T7 & $66.97^{\mathrm{a}}$ & $6.48^{\mathrm{c}}$ & $3.93^{\mathrm{D}}$ \\
\hline LSD & 0.8913 & 0.6633 & 0.6340 \\
\hline \multicolumn{4}{c}{ Lemon waste extract (P2) } \\
\hline T1 & $61.43^{\mathrm{e}}$ & $5.06^{\mathrm{c}}$ & $3.93^{\mathrm{c}}$ \\
T2 & $69.60^{\mathrm{D}}$ & $7.33^{\mathrm{ab}}$ & $4.37^{\mathrm{Dc}}$ \\
T3 & $69.40^{\mathrm{D}}$ & $7.31^{\mathrm{ab}}$ & $5.17^{\mathrm{a}}$ \\
T4 & $63.67^{\mathrm{a}}$ & $7.69^{\mathrm{a}}$ & $5.53^{\mathrm{a}}$ \\
T5 & $73.13^{\mathrm{a}}$ & $7.12^{\mathrm{ab}}$ & $5.10^{\mathrm{ab}}$ \\
T6 & $70.00^{\mathrm{D}}$ & $8.09^{\mathrm{a}}$ & $5.20^{\mathrm{a}}$ \\
T7 & $66.97^{\mathrm{c}}$ & $6.48^{\mathrm{D}}$ & $3.80^{\mathrm{c}}$ \\
\hline LSD & 1.128 & 1.048 & 0.7610 \\
\hline
\end{tabular}

Total amino acids, organic acids and proline in maize grains

Experimental results of total amino acids, organic acids and proline content of maize are summarized in Table 8. Data reveal that total amino acid and organic acid contents increased in all treatment for both two extracts (P1 or P2) relative to mineral fertilizer as a control. Regarding to the proline content, data show that at T4 treatment for P1 extract, the value of proline was higher than control. This accumulation of proline might result from interaction between microorganisms in soil and increasing of protein and or might be due to enzyme stabilization and or osmoregulation (Abou El-Magd et al., 2008). On the contrary, the values of proline in other treatments were lower than the control. These results may be attributed to the high content of P1 or P2 extract in amino and organic acids as shown in Table 1, these constituent are a well known biostimulant which has positive effects on plant growth, yield and significantly mitigates the injuries caused by abiotic stresses such as salinity. The present findings are in agreement with those reported by Kowalczyk and Zielony (2008). Amino acids as organic nitrogenous compounds stimulated cell growth acting as buffers maintaining 
favorable $\mathrm{pH}$ value within the plant cell as well as synthesizing other organic compounds, such as protein, amines, purines and pyrimidines, alkaloids, vitamins, enzymes, terpenoids and others (Goss, 1973). Bidwell (1980) stated that, the importance of amino acids came from their widely uses for the biosynthesis of a large variety of non-protein nitrogenous materials, i.e. pigment, vitamins, coenzymes, purine and pyrimidine bases. Amino acids could directly or indirectly influence the physiological activities of plant growth and development, through their regulatory effects on production of gibberellins in plant tissues (Waller and Nowaki, 1978).

\section{Indole acetic acid and gibberillic acid in maize grains}

Data presented in Table (9) illustrate the effect of P1 or P2 extract on hormone content in maize grains. For P1 extract, there was progressive increment in indole acetic acid averages of maize grain as a result of treated with T2, T3, and T6 treatments compared with control. The highest value of gibbrillic was recorded in treatments of T3 relative to control. Regarding the P2 extract treatments, the highest value of IAA was recorded in T3, T4, and T6 treatment. No significant effect was observed in other treatments relative to control. Finally, it is worth mention that, the values of Gibbrillic acid hormone in all treatments were recorded the higher values than in mineral fertilizer treatment as a control. These results may be due to the presence of indole acetic acid and giberllic acid in extracts as shown in Table (1). The beneficial effect of food industries waste extracts application is as a result of many components that may effect synergistically.

Table (8): Effect of some food industry wastes extracts on amino and organic acids of maize plant under field experiment

\begin{tabular}{|c|c|c|c|}
\hline \multirow[t]{2}{*}{ Treatment } & \multicolumn{2}{|c|}{ Total amino acids \% Organic acid (ppm) } & Proline \% \\
\hline & \multicolumn{3}{|c|}{ Molasses yeast $(\mathrm{P} 1)$} \\
\hline $\mathrm{T} 1$ & $6.71^{f}$ & $1472^{b}$ & $1.57^{\mathrm{b}}$ \\
\hline T2 & $13.35^{b}$ & $3132^{a}$ & $1.23^{c}$ \\
\hline T3 & $13.96^{a}$ & $3328^{a}$ & $1.06^{d}$ \\
\hline T4 & $12.15^{c}$ & $1887^{b}$ & $1.87^{\mathrm{a}}$ \\
\hline T5 & $12.58^{c}$ & $2865^{a}$ & $0.96^{\mathrm{e}}$ \\
\hline T6 & $11.50^{d}$ & $3077^{a}$ & $0.88^{e}$ \\
\hline T7 & $10.74^{e}$ & $1549^{b}$ & $1.48^{\mathrm{b}}$ \\
\hline \multirow[t]{2}{*}{ LSD } & 0.5247 & 723.5 & 0.09744 \\
\hline & \multicolumn{3}{|c|}{ Lemon waste extract (P2) } \\
\hline $\mathrm{T} 1$ & $6.71^{\mathrm{e}}$ & $1472^{b}$ & $1.567^{\mathrm{a}}$ \\
\hline T2 & $11.04^{\mathrm{cd}}$ & $1933^{\mathrm{ab}}$ & $1.05^{\mathrm{e}}$ \\
\hline T3 & $11.08^{c d}$ & $2907^{a}$ & $0.98^{f}$ \\
\hline $\mathrm{T} 4$ & $13.14^{a}$ & $3056^{a}$ & $1.11^{d}$ \\
\hline T5 & $11.42^{\mathrm{c}}$ & $2688^{a b}$ & $0.95^{f}$ \\
\hline T6 & $12.65^{b}$ & $3108^{a}$ & $1.27^{c}$ \\
\hline $\mathrm{T} 7$ & $10.74^{d}$ & $1549^{b}$ & $1.48^{b}$ \\
\hline LSD & 0.4839 & 1150 & 0.05626 \\
\hline
\end{tabular}


Table (9): Effect of some food industry wastes extracts on hormone content $(\mu \mathrm{g} / \mathrm{g})$ of maize plant under field experiment

\begin{tabular}{|c|c|c|}
\hline \multirow[t]{2}{*}{ Treatment } & Indole acetic acid & Gibrellic \\
\hline & \multicolumn{2}{|c|}{ Molasses yeast (P1) } \\
\hline $\mathrm{T} 1$ & $382.7^{b}$ & $1088^{e}$ \\
\hline $\mathrm{T} 2$ & $702.3^{a}$ & $5408^{b}$ \\
\hline T3 & $727.7^{\mathrm{a}}$ & $6575^{a}$ \\
\hline $\mathrm{T} 4$ & $366.0^{b}$ & $1920^{d}$ \\
\hline T5 & $431.3^{b}$ & $1438^{\text {de }}$ \\
\hline T6 & $690.7^{\mathrm{a}}$ & $4063^{c}$ \\
\hline $\mathrm{T} 7$ & $390.0^{b}$ & $1128^{e}$ \\
\hline \multirow[t]{2}{*}{ LSD } & 115.8 & 610.3 \\
\hline & \multicolumn{2}{|c|}{ Lemon waste extract (P2) } \\
\hline $\mathrm{T} 1$ & $382.7^{b}$ & $1088^{d}$ \\
\hline $\mathrm{T} 2$ & $253.3^{b}$ & $1205^{c d}$ \\
\hline T3 & $692.7^{\mathrm{a}}$ & $2855^{a}$ \\
\hline $\mathrm{T} 4$ & $543.7^{\mathrm{a}}$ & $2200^{b}$ \\
\hline T5 & $326.0^{b}$ & $1217^{c}$ \\
\hline T6 & $690.7^{\mathrm{a}}$ & $2312^{b}$ \\
\hline T7 & $390.0^{b}$ & $1128^{\mathrm{cd}}$ \\
\hline LSD & 144.8 & 115.2 \\
\hline
\end{tabular}

The application of these extracts significantly increased grain yield as well as improved nutritional values of seeds, i-e., protein, amino acid, carbohydrates, and hormones. The efficiencies of P1 and P2 extracts as a fertilizer or amendments are very different. There was excellent potential to obtain a liquid natural fertilizer and amendment using molasses yeast. The effect of fodder molasses yeast extract as a fertilizer and an amendment were summarized in the following order: P1 only (as a fertilizer) $>\mathrm{P} 1+$ mineral Fertilizer (as amendment) > P1 + additive some micronutrients + mineral fertilizer (as amendment) > P1 + compost (as amendment) compared to mineral fertilizer or compost as control. On the other hand, the best results of lemon waste extract (P2) were obtained as amendment rather than a fertilizer. The effect of lemon waste extract was summarized in the following order: P2 + some micronutrients + mineral fertilizer (as amendment) > P2 + compost (as amendment) > P2 + mineral Fertilizer (as amendment) compared to mineral fertilizer or compost as control. Generally, natural extracts from food industries waste constitute a source of many substances, valuable from the point of view of plant physiology, which particularly help plants adapt to stressful conditions such as biologically active alginic acids, polyphenols, free amino acids, and particularly natural plant phytohormones. The increased yield may be due to the presence of some growth promoting substances such as IAA and IBA, gibberellins, cytokinins, micronutrients, vitamins and amino acids (Challen and Hemingway, 1966). These compounds were able to stimulate growth as a result of enhancement of 
protein synthesis and cell division, and mobilization of nutrients needing for growth. The nutritional quality of grain such as carbohydrate, protein and minerals also improved under the influence of treatment (Zodapea, et al., 2009). The increase in protein content in treated plants with residues extracts is in agreement with the results obtained by Kannan and Tamilselvan, (1990), they attributed the increase in protein content to the absorption of most of the necessary elements by plant.

\section{Conclusion}

It could be noticed that there is a positive effect of molasses yeast and lemon extract on the growth, development and consequently yields of field crops. There was excellent potential to obtain a natural liquid organic fertilizer and amendment using molasses yeast. On the other hand, the best results of lemon waste extract were obtained as an amendment rather than a fertilizer. So, these extracts can be used to focus on waste minimization in food industry that circumvents the environmental problems caused by this waste. Also, food industries waste can be used to produce natural liquid organic fertilizer and amendments for soil and plant to decrease the use of chemical fertilizers and help lower production environmental hazards on a long-term basis.

\section{Acknowledgements}

Thanks are due to Dr. Somaya Ahmed Hassanein and Dr. Samira, ElSayed Mahrous, professor of soil science for providing with information and technical assistance.

\section{REFERENCES}

Abou El-Magd, M.M.; Zaki, M.F. and Abou-Husseinc, S.D. (2008). Effect of Organic Manure and Different Levels of Saline Irrigation Water on Growth, Green Yield and Chemical Content of Sweet Fennel. Australian Journal of Basic and Applied Sciences, 2(1): 90-98.

AOAC., (1970). "Official Methods of Analysis". A.O.A.C., Washington, D.C. AOAC., (1980). "Official Methods of Analysis". A.O.A.C., Washington, D.C.

Ashok kumar, K.; Narayani, M.; Subanthini A.; and Jayakumar, M.; (2011). Antimicrobial Activity and Phytochemical Analysis of Citrus Fruit Peels Utilization of Fruit Waste. International Journal of Engineering Science and Technology, 3 (6): 5414-5421.

Bates, L.S.; Waldren, R.P. and Tear, I.D. (1973). Rapid determination of free proline for water-stress studies. Plant and Soil, 39: 205-207.

Bidwell, R. (1980). "Plant Physiology". 2nd Ed., Callier MacMillan Publisher, London, New York.

Challen, S.B. and Hemingway, J.C., (1966). Growth of higher plants in response of feeding with seaweed extracts. Proc. Fifth Int. Seaw. Symp. 359-367. 
Cho, K. Y.; Sakurai. A. and Kamiya, Y. (1979). Effects of the new plant growth retardants of quaternary ammonium iodides on gibberellin biosynthesis in Gibberella fujikuroi. Plant Cell Physiol 20: 25-81.

Djilas, S.; Canadanovic-Brunet, J. and Cetkovic, G. (2009). By-products of fruits processing as a source of phytochemicals, Chem. Ind. Chem. Eng. Q.,15, 191-202.

Echegaray, O.; Carvalho, J.; Fernandes, A.; Sato, S.; Aquarone, E. and Vitolo, M., (2000). Fed-batch culture of Saccharomyces cerevisiae in sugar-cane blackstrap molasses: invertase activity of intact cells in ethanol fermentation. Biomass Bioenergy, 19, 39-50.

El-Zaher, H.; Awad, A. M. and Salem, M. A. (2001). Combined effect of farmyard manure and $\mathrm{N}$-fertilizer on wheat production, NPK uptake and $\mathrm{N}$-use efficiencies under highly calcareous soil conditions. J. Agric. Sci. Mansoura Univ., 26(12):8227-8245.

Fathy, M.F.; Abd EL-motagally, A. and Attia, K.K. (2009). Response of sugar beet plants to nitrogen and potassium fertilization in sandy calcareous soil. Int. J. Agric. Biol., 11: 695-700.

Goss, J. A. (1973). Amino acid synthesis and metabolism. In: Physiology of Planta and their Cells. Pergamon Press, Inc.,New York.

Guolin, H.; Shi, J.; Zhang, K. and Huang, X. (2012). Application of Ionic Liquids in the Microwave-Assisted Extraction of Pectin from Lemon Peels Journal of Analytical Methods in Chemistry, 1-8.

Hetter, B. (1985). Utilization of sulphur for amendment on calcareous soil in Jordan. Proc. 2nd Arab. Regional Conf. on Sulphur and its usages, Ryiadh, Saudi Arabia, 1:85-100.

Inckel, M.; Smet D.; Tersmette T. and Veldkamp, T. (1996). "The preparation and use of compost". Fourth Edition Trans by Verheij Wagenningen EWM. Netherlands, p. 28.

Jackson, M.L. (1973). "Soil Chemical Analysis". Prentice Hall of India Pvt. Ltd., New Delhi.

Jamil, M. and Qasim, M. (2008). Integrated use of boiler ash as organic fertilizer and soil conditioner with NPK in calcareous soil. Songklanakarin J. Sci. Technol. 30 (3), 281-289.

Kannan, L. and Tamilselvan, C., (1990). Effect of seaweed manures on Vigna radiata. Perspectives in phycology. (Prof. M.O.P. lyengar Centenary Celebration Volume) V.N. Rajarao (Ed.), pp. 427-430.

Kineber, M.; El-Masry, A. and Gohar, M. (2004). Effect of sulphur application and nitrogen fertilization on yield and its quality for some flax varieties in alkaline soil. Ann. Agric. Sci., 49(1):53-69.

Kong, W.D.; Zhu, Y.G.; Fu, B.J., Han, X.Z.; Zhang, L. and He, J.Z. (2008). Effect of long-term application of chemical fertilizers on microbial biomass and functional diversity of a black soil. Pedosphere 18: 801 808.

Kowalczyk, K. and T. Zielony, (2008). Effect of Aminoplant and Asahi on yield and quality of lettuce grown on rockwool. Conf.of biostimulators in modern agriculture, Warsaw, Poland. 
Lan, Y.; Zhang, Y.; Liu, Y.; Sheng, Y. and Wentian, S. (2012). Research on Food Waste Resource Utilization and Processing Technologies. International Conference on Ecology, Waste Recycling, and Environment Advances in Biomedical Engineering, 7, 105-109.

Li, S.; Lo, C. and Ho, C. (2006). Hydroxylated polymethoxyflavones and methylated flavonoids in sweet orange (Citrus sinensis) peel. Journal of Agricultural and Food Chemistry, 54: 4176-4185.

Li, S.; Gu, S.; Tana, X. and Zhang, Q. (2009). Water quality in the upper Han River basin, China: The impacts of land use/land cover in riparian buffer zone. J. Hazard. Mater. 165: 317-324.

Lucia, M; Mendoz, M. and Manca, N. (2010). Antagonistic interaction between yeasts and lactic acid bacteria of oenological relevance: Partial characterization of inhibitory compounds produced by yeasts. Food reacreash international, 43 (8): 1990-1998.

Mahadevan, A. and Chandramohan, D. (1966). Auxin production by the rice leaf blight fungus, Helminthosporium oryzae and other Helminthosporium. Ind Phylopath Soc Symp Bull. 3: 91-96.

Moore, S. and Stein, W. H. (1954). A modified ninhydrin reagent for the photometric determination of amino acids and related compounds. $J$. Biol Chem., 211:907-913.

Murphy, R. P. (1958). Extraction of plant samples and the determination of total soluble carbohydrates. J. Sci. Food Agric. 9, 714-717.

Nelson, W.L. (1978). Influence of $K$ on tolerance to stress (North American experience). In Sekhon GS (Ed.) Potassium in soils and crops Potash Res. Inst. of India. New Delhi, pp: 203-211.

Nofemele, Z.; Pratyoosh S., Arthur, T.; Kugen, P. and Suren, S. (2012). Improvement of ethanol production from sugarcane molasses through enhanced nutrient supplementation using Saccharomyces cerevisiae. Journal of Brewing and Distilling, 3(2), pp. 29-35.

Ouda B.A. and Mahadeen A.Y. (2008). Effect of fertilizers on growth, yield, yield components, quality and certain nutrient contents in broccoli (Brassica oleracea). Int. J. Agri. Biol. 10: 627-632.

Page, A.; Miller, R.; and Keeney, D. (1982). "Methods of Soil Analysis". II: Chemical and Microbiological Properties, 2nd ed.Am.Soc.Agron.Inc; Soil. Soil Sci Soc. Am. Inc, Madison, Wisconsin U.S.A.

Sanchez, O. and Cardona, C. (2008). Trends in biotechnological production of fuel ethanol from different feedstocks. Bioresource Technology, 99, 5270-5295.

Shata, S.; Safaa, A. and Hanan, S. (2007). Improving Calcareous Soil Productivity by Integrate Effect of Intercropping and Fertilizer Research, Journal of Agriculture and Biological Sciences, 3(6): 733739.

Sherif, M.; Ibrahim,, H.; Ibrahim, A.K. and Amal, M. (2012). Comparative Study of the Effects of Some Organic Extract on Sugar Beet Yield Under Saline Conditions Australian Journal of Basic and Applied Sciences, 6(10): 664-674. 
Sim E.; and $\mathrm{Wu}, \mathrm{T}$. (2010). The potential reuse of biodegradable municipal solid wastes (MSW) as feedstocks in vermicomposting. J. Sci. Food Agric. 90: 2153-2162.

Smith, D.; Paulsen, G.M. and Raguse, C.A. (1964). Extraction of total available carbohydrates from grass and legume tissue. Plant Physiol. 39: 960 -962.

Snedecor, G.W. and Cochran, W.G. (1980). Statistical Method. 7th Ed., lowa State Univ. Press, Ames, lowa, USA.

Waller, G. R. and Nowaki, E. K. (1978). Alkaloid, Biology and Metabolism in Plants. Plenum Press, New York, 85-247.

Unyayar, S.; Topcuo, F. and .Nyayar, A. (1996). A modified method for extraction and identification of indole-3-acetic acid (IAA), gibberellic acid (GA3), abscisic acid (ABA) and zeatin produced by Phanerochate chrysosporium ME 446. Bulg J Plant Physiol 22 (3-4): 105-110.

Zodapea S.T.; Mukherjeea S.; Reddya M.P. and Chaudharya D.R. (2009). Effect of Kappaphycus alvarezii Doty ex silva. extract on grain quality, yield and some yield components of wheat (Triticum aestivum L.). International Journal of Plant Production, 3(2): 97-101.

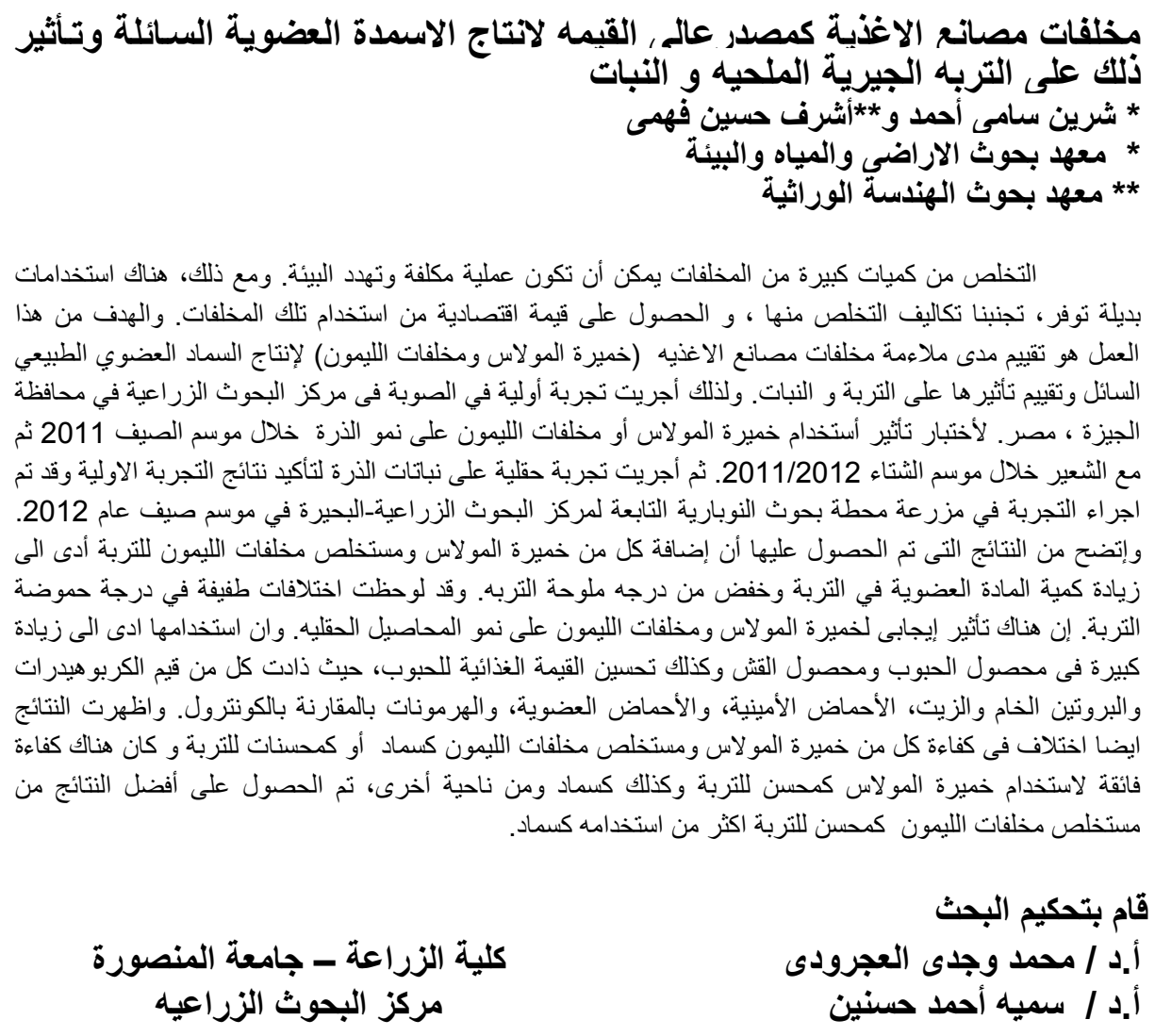


J. Soil Sci. and Agric. Eng., Mansoura Univ., Vol. 5 (1), January, 2014 